\title{
A Cross Sectional Study on Correlation of Quantitative C - reactive protein with CD4 Count in Patients of HIV on Art
}

\author{
Alok Gahlot ${ }^{1}$, Pooja Gahlot ${ }^{2}$, Jitendra Acharya ${ }^{3}$ \\ ${ }^{1}$ (M.D. Medicine) Senior Resident Department of Medicine P.D.U. Medical College Churu, ${ }^{2}$ M.S. Gynae \&Obs., Assistant Professor Department of Gyne \& \\ Obs. P.D.U Medical College Churu, ${ }^{3}$ S.P. Medical College Bikaner.
}

\section{Abstract}

Background: Over the past two decades with the advent of highly active antiretroviral therapy (HAART), there is a substantial increase in the life span of HIV patients. Hence, the focus has now shifted to managing long-term complications of HIV infection and improving the quality of life of HIV patients, especially in developed nations. On the other hand, in developing nations, the ever-growing incidence of HIV infection has placed a huge burden on their frail economy, so there is a growing need for simplifying HIV treatment protocols and for having cheaper alternatives for monitoring disease activity. Subjects and Methods: The present study was a cross sectional hospital based study for a period of twelve months from 1st Nov. 2015 to 31st Oct. 2016 at ART center P.B.M. Hospital, Bikaner. 100 HIV+ patients on ART were included in the study by consecutive sampling technique. Out of 100 patients, 50 were symptomatic and included in study group and remaining 50 were asymptomatic and taken as controls. Results: 37 (74\%) patients in study group had CRP levels $>6 \mathrm{mg} / \mathrm{lit}$ (normal level <6 mg/lit). Out of 37, 19 subjects (38\% of total) had CRP level $>20 \mathrm{mg} / \mathrm{lit}$. While in control group, 44 subjects (88\%) had CRP level <6 mg/lit. Only 6 (12\%) subjects of control group had CRP level $>6 \mathrm{mg} / \mathrm{lit}$. None of control subjects had CRP level $>20 \mathrm{mg} / \mathrm{lit}$. The CRP levels and CD4 count were negatively correlated in study group and this was observed to be statistically significant $(\mathrm{p}=0.04)$ whereas in control group, the CRP levels and CD4 counts were found to be very weakly positively correlated and this correlation was observed to be statistically insignificant. Conclusion: There was statistical significant difference between CRP range and levels in both the groups. Also statistical significant difference between CD4 count range in both the groups. In our study, $38 \%$ of the study group patients had CRP $>20 \mathrm{mg} / \mathrm{l}$ whereas $88 \%$ of the control subjects had $\mathrm{CRP}$ of $<6 \mathrm{mg} / \mathrm{l}$.

Keywords: HIV, CRP, CD 4, HAART.

Corresponding Author: Dr. Pooja Gahlot, M.S. Gynae \&Obs., Assistant Professor Department of Gyne \& Obs. P.D.U Medical College Churu.

Received: October 2019

Accepted: October 2019

\section{Introduction}

Over the past two decades with the advent of highly active antiretroviral therapy (HAART), there is a substantial increase in the life span of HIV patients. Hence, the focus has now shifted to managing long-term complications of HIV infection and improving the quality of life of HIV patients, especially in developed nations. On the other hand, in developing nations, the ever-growing incidence of HIV infection has placed a huge burden on their frail economy, so there is a growing need for simplifying HIV treatment protocols and for having cheaper alternatives for monitoring disease activity. ${ }^{[1]}$

High-sensitivity C-reactive protein (hsCRP) has been touted as a potential solution for both these problems. First, hs CRP is considered to be a potential biomarker for predicting longterm disease progression and cardiovascular disease (CVD) risk, which is one of the major long-term complications in HIV patients. Second, it is also considered to be a marker for predicting mortality and as a tool for routine monitoring of disease activity with a potential to replace traditional costlier measures such as CD4 count and HIV RNA load.

There are reports on the association of high levels of plasma highly sensitive C-reactive protein (CRP) and HIV disease progression. ${ }^{[2,3]} \mathrm{CRP}$ is an acute phase protein whose levels increase with the infection and inflammation. CRP is an important component of the innate immune system, which is synthesized in the hepatocytes, primarily in response to IL-6 and other cytokines. Normally its serum concentration is less than $6 \mathrm{mg} / \mathrm{L}$, but during inflammation its level may increase 10,000-folds. Increase in CRP level can be detected as early as 5-10 hours after tissue damage. Opportunistic infection accounts for the majority of death in untreated patients with HIV. These infections usually are a result of activation of latent infections which are normally kept in check by robust immune system. The treatment response of the individual to the underlying opportunistic infections varies considerably and depends on the immune power (CD4 COUNT). CRP levels increase with infection and there exists a negative correlation between CRP and CD4 count ${ }^{[4]}$ However, it is unclear whether pre-ART inflammation adversely impacts 
long-term gain in CD4 T-cell count (henceforth CD4 count) post-ART, independent of CD4 count at ART initiation ${ }^{[5,6,7]}$ Immune activation has been demonstrated to be a significant contributor to HIV disease progression in multiple studies. ${ }^{[8,9,10,11]}$ It was observed that this immune activation was associated with increased levels of bacterial components in blood, which was hypothesized to be due to increased microbial translocation from the gastrointestinal tract of patients and this microbial translocation was hypothesized to contribute for HIV disease progression. ${ }^{[12,13]}$ Naturally, CRP being an acute phase reactant should increase in patients with HIV disease progression if it is associated with microbial translocation and immune activation as hypothesized instudies. ${ }^{[14,15]}$

\section{Subjects and Methods}

The present study was a cross sectional hospital based study for a period of twelve months from 1st Nov. 2015 to 31st Oct. 2016 at ART center P.B.M. Hospital, Bikaner.

\section{Sample Size And Sampling Technique}

$100 \mathrm{HIV}+$ patients on ART were included in the study by consecutive sampling technique. Out of 100 patients, 50 were symptomatic and included in study group and remaining 50 were asymptomatic and taken as controls.

\section{Inclusion Criteria}

- Age more than 18 years

- Patients seropositive for HIV-antibodies

- Patients on ART at least 6 months

- Ready to give consent

\section{Exclusion Criteria}

- Patients below age of 18 years.

- Patients who were known case of rheumatoid arthritis, connective tissue disorders and cancers.

- Patients with pre existing liver, kidney and heart disease.

HIV positive patients on ART were enrolled for the study with their informed consent. All the patients were tested for the HIV antibodies at the ICTC P.B.M.Hospital Bikaner.

\section{Analytical Methods Sample}

The blood sample was collected under standard precautions at ART center for measurement of CD4 count in an EDTA vial and for CRP in a sterile plane vial without anticoagulant. The samples were immediately sent to the Microbiology laboratory for further processing. For CRP measurement, the serum sample was used and processed in the serology lab of the microbiology laboratory. CRP estimation was done by latex enhanced nephelometry.

\section{Data Analysis}

The information thus collected was entered into excel sheet and analyzed with the help of SPSS 22.0 in form of frequencies, mean, SD, correlation and appropriate test of significance, considering $\mathrm{p}=0.05$ as cut off level of significance.

\section{Results}

We found that [Table 1] shows that $37(74 \%)$ patients in study group had CRP levels $>6 \mathrm{mg} /$ lit (normal level $<6$ $\mathrm{mg} / \mathrm{lit}$ ). Out of 37, 19 subjects (38\% of total) had CRP level $>20 \mathrm{mg} / \mathrm{lit}$. While in control group, 44 subjects $(88 \%)$ had CRP level $<6 \mathrm{mg} / \mathrm{lit}$. Only 6 (12\%) subjects of control group had CRP level $>6 \mathrm{mg} /$ lit. None of control subjects had CRP level $>20 \mathrm{mg} / \mathrm{lit}$.

[Table 2] shows comparative description of CD4 count range between 2 groups. $8 \%$ of study subjects as compared to $44 \%$ patients in control group were having CD4 count $>500 / \mathrm{cu}$ $\mathrm{mm}$.

$46 \%$ of patients in study group were having CD4 count in the range of 200-500 cells/cu mm whereas among controls this proportion was higher $(52 \%)$. Around $30 \%$ cases in study group had CD4 count in range of 100-200 cells/cu mm while only $4 \%$ cases in control group had CD4 count in this range. None of controls were having CD4 count $<100$ cells/cu mm whereas among study group, $16 \%$ cases were having CD4 count $<100$ cells/cu mm. Therefore it was observed that study group patients who had Opportunistic infections had lower ranges of CD4 counts as compared to control group and this difference was statistically significant $(\mathrm{p}=0.0001)$. [Table 3] Also the mean CD4 count in study group was significantly lower as compared to control group ( $\mathrm{p}=0.0001)$.[Table 4] The CRP levels were increased till the CD4 count $150 \mathrm{cu} \mathrm{mm}$, CRP levels were minimum in patients with CD4 count between 151-200. The variation was statistically significant. [Table 5] The CRP levels and CD4 count were negatively correlated in study group and this was observed to be statistically significant $(\mathrm{p}=0.04)$ whereas in control group, the CRP levels and CD4 counts were found to be very weakly positively correlated and this correlation was observed to be statistically insignificant. [Table 6] The CRP levels and ART duration were negatively correlated in study group and this was observed to be statistically insignificant $(\mathrm{p}=0.172)$ whereas in control group, the CRP levels and CD4 counts were found to be very weakly positively correlated and this correlation was also observed to be statistically insignificant $(\mathrm{p}=0.665)$.

Table 1: Distribution of subjects according to CRP Range

\begin{tabular}{|l|l|l|l|}
\hline \multirow{2}{*}{ Range of CRP (mg/lit) } & Group & \multirow{2}{*}{ P value } \\
\cline { 2 - 3 } & Study & Control & \\
\hline$<6$ & $13(26 \%)$ & $44(88 \%)$ & \multirow{2}{*}{$\chi^{2}=35.84$} \\
\hline $6-10$ & $5(10 \%)$ & $2(4 \%)$ & \\
\hline $10-15$ & $7(14 \%)$ & $3(6 \%)$ & 0.0001 \\
\hline $15-20$ & $6(12 \%)$ & $1(2 \%)$ & \\
\hline$>20$ & $19(38 \%)$ & $0(0 \%)$ & \\
\hline Total & $50(100 \%)$ & $50(100 \%)$ & \\
\hline
\end{tabular}

Table 2: Distribution of subjects according to CD4 count Range

\begin{tabular}{|l|l|l|l|}
\hline \multirow{2}{*}{$\begin{array}{l}\text { Range of CD 4 (cells per } \\
\text { cumm) }\end{array}$} & Group & \multirow{2}{*}{ P value } \\
\cline { 2 - 3 } & Study & Control & \\
\hline$<50$ & $2(4 \%)$ & $0(0 \%)$ & \multirow{2}{*}{$\chi^{2}=29.98$} \\
\hline $50-100$ & $6(12 \%)$ & $0(0 \%)$ & \\
\hline $100-200$ & $15(30 \%)$ & $2(4 \%)$ & \multirow{2}{*}{$\begin{array}{c}0.0001 \\
\text { (Significant) }\end{array}$} \\
\hline $200-500$ & $23(46 \%)$ & $26(52 \%)$ & \\
\hline$>500$ & $4(8 \%)$ & $22(44 \%)$ & \\
\hline Total & $50(100 \%)$ & $50(100 \%)$ & \\
\hline
\end{tabular}


Table 3: Distribution of subjects according to CD4 Count CD 4 count (cells per cumm)

\begin{tabular}{|l|l|l|}
\hline Group & Z test \\
\hline Study & Control & \\
\hline 249.96 & 424.74 & $\mathrm{Z}=32.453$ \\
\pm 171.25 & \pm 166.51 & $\mathrm{P}=0.0001$ \\
& & (Significant) \\
\hline
\end{tabular}

Table 4: Changes in CRP levels among Cases as per CD4 count

\begin{tabular}{|l|l|l|}
\hline & CRP Level & \\
\hline CD4 count & Mean & SD \\
\hline$<50$ & 8.4 & .01 \\
\hline $51-100$ & 37.5 & 18.19 \\
\hline $101-150$ & 80.94 & 48.51 \\
\hline $151-200$ & 12.05 & 9.91 \\
\hline $201-500$ & 19.19 & 18.02 \\
\hline$>500$ & 35.06 & 30.57 \\
\hline
\end{tabular}

Table 5: Correlation of CRP and CD 4 count in both the groups.

\begin{tabular}{|l|l|l|}
\hline & $\begin{array}{l}\text { Pearson Correlation } \\
(\mathbf{r})\end{array}$ & P value \\
\hline $\begin{array}{l}\text { Study group (CRP with } \\
\text { CD4) }\end{array}$ & $1:-0.291$ & 0.040 (Significant) \\
\hline $\begin{array}{l}\text { Control group (CRP } \\
\text { with CD4) }\end{array}$ & $1: 0.089$ & $\begin{array}{l}0.539 \text { (Not } \\
\text { Significant) }\end{array}$ \\
\hline
\end{tabular}

Table 6: Correlation of CRP and ART duration in both the groups.

\begin{tabular}{|c|c|c|}
\hline 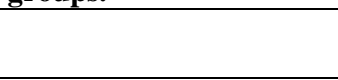 & $\begin{array}{l}\text { Pearson } \\
\text { Correlation (r) }\end{array}$ & P value \\
\hline $\begin{array}{l}\text { Study group (CRP with ART } \\
\text { duration) }\end{array}$ & $1:-0.205$ & $\begin{array}{l}0.172 \text { (Not } \\
\text { Significant) }\end{array}$ \\
\hline $\begin{array}{l}\text { Control group (CRP with } \\
\text { ART duration) }\end{array}$ & $1: 0.065$ & $\begin{array}{l}0.665 \text { (Not } \\
\text { Significant) }\end{array}$ \\
\hline
\end{tabular}

\section{Discussion}

$38 \%$ of the study group patients had CRP $>20 \mathrm{mg} / \mathrm{l}$ whereas $88 \%$ of the control subjects had CRP of $<6 \mathrm{mg} / \mathrm{l}$. Nearly $46 \%$ of the study subjects had CD 4 count less than 200/cu $\mathrm{mm}$ as compared to just $4 \%$ in the control group.

Ugwu MC et al (2016) ${ }^{[16]}$ also observed that CRP levels were significantly higher in Cases as compared to controls and CD4 count was significantly lower among cases. Reingold JS et $\mathrm{al}^{[17]}$ compared CRP levels between 1135 HIV infected patients enrolled in a cross sectional study (of whom $22 \%$ were HCV coinfected) and $251 \mathrm{HIV}$ uninfected controls and although the diagnosis of AIDS was associated with higher CRP levels, current CD4-cell count and HIV RNA level were not. Lau B et al observed that levels of CRP more than $2.3 \mathrm{mg} / \mathrm{L}$ were associated with a decreased time to the development of AIDS compared with individuals with CRP levels of $1.2 \mathrm{mg} / \mathrm{L}$ or less.

The CRP levels and CD4 count were negatively correlated in study group and this was observed to be statistically significant $(\mathrm{p}=0.04)$. Similar findings were observed by Vishwanath A et al (2016). ${ }^{[18]}$ In present study in control group, the CRP levels and CD4 counts were found to be very weakly positively correlated and this correlation was observed to be statistically insignificant. Similarly Andrew et al (2010) ${ }^{[19]}$ in a longitudinal study divided study population into three groups- long-term nonprogressor (i.e., CD4 >600 cells $/ \mu 1$ at $>7$ years after seroconversion), standard progressors (i.e., death $>5$ but $<9$ years after seroconversion), and rapid progressors (i.e., death within 4 years after seroconversion) and observed that there is a significant association of immune activation as measured by CRP levels with HIV disease progression. Drain et al (2007) ${ }^{[20]}$ observed that CRP was not better than CD4 count or viral load in predicting maternal mortality outcomes. More the infection, higher will be their CRP level (as it is an acute phase reactant) and higher is their chances of progression to AIDS. There was significant difference between CRP range and levels in both the groups. Also significant difference between CD4 count range in both the groups.

The CRP levels and ART duration were negatively correlated in study group and this was observed to be statistically insignificant $(\mathrm{p}=0.172)$ whereas in control group, the CRP levels and CD4 counts were found to be very weakly positively correlated and this correlation was also observed to be statistically insignificant $(\mathrm{p}=0.665)$.

Devi BS et al (2010-2012 $)^{[21]}$ in their study at Imphal observed in a multivariate analysis of HAART with OIs for time frames 2, 3 and 4 were 0.047, 0.207 and $0.000(<0.05$ significant) respectively.Tahir A et al (2013) ${ }^{[22]}$ conducted a study to assess correlation between c-reactive protein and CD4+ cell count in HIV-infected and HIV/PTB co-infected patients at the University of Maiduguri Teaching Hospital (UMTH), Maiduguri, Nigeria included 120 consecutive HIVinfected patients comprising $60 \mathrm{HIV}+$ only and $60 \mathrm{HIV} / \mathrm{PTB}$ co-infected patients and 60 apparently healthy HIVseronegative age- and sex-matched controls were recruited. The Pearson's product moment correlation coefficients (r) for the correlation between CRP and CD4+ cell count were $0.596(\mathrm{p}=0.000)$ for HIV+, $-0.365(\mathrm{p}=0.004)$ for HIV/PTB patients and $+0.147(\mathrm{p}=0.263)$ for healthy controls. They found a strong linear negative correlation between CRP and $\mathrm{CD} 4+$ cell count in HIV-infected patients as well as those with HIV/PTB co-infection. Skogmar S et al (2015) $)^{[23]}$ studied about plasma levels of c-reactive protein (CRP) in tuberculosis (TB) with and without HIV coinfection in relation to CD4 cell count and observed that Levels of CRP were elevated in TB patients (CRP: HIV+/TB $+36 \mu \mathrm{g} / \mathrm{ml}$, $\mathrm{HIV}-/ \mathrm{TB}+33 \mu \mathrm{g} / \mathrm{ml}$, controls $0.5 \mu \mathrm{g} / \mathrm{ml}$ ). CRP levels were inversely correlated $(-0.25, \mathrm{p}<0.001)$ to $\mathrm{CD} 4$ cell count.Lawn $\mathrm{SD}$ et $\mathrm{al}^{[24]}$ observed that CRP concentrations were much higher among TB cases.

\section{Conclusion}

There was statistical significant difference between CRP range and levels in both the groups. Also statistical significant difference between CD4 count range in both the groups. In our study, $38 \%$ of the study group patients had CRP > $20 \mathrm{mg} / \mathrm{l}$ whereas $88 \%$ of the control subjects had CRP of $<6 \mathrm{mg} / \mathrm{l}$.Nearly $46 \%$ of the study subjects had CD 4 count less than 200 as compared to just $4 \%$ in the control group.CRP level was significantly higher in study group and CD 4 count was higher in the control group. The CRP levels and CD4 count were negatively correlated in study group and this was observed to be statistically significant $(\mathrm{p}=0.04)$ whereas in control group, the CRP levels and CD4 counts were found to be very weakly positively correlated and this 
correlation was observed to be statistically insignificant. The CRP levels and ART duration were negatively correlated in study group and this was observed to be statistically insignificant $(p=0.172)$ whereas in control group, the CRP levels and CD4 counts were found to be very weakly positively correlated and this correlation was also observed to be statistically insignificant $(\mathrm{p}=0.665)$.

\section{References}

1. Joint United Nations Program on HIV/AIDS. 14 January 2007 accession date. AIDS epidemic update: December 2005. http://www.unaids.org/epi/2005.

2. Lau, B., A. R. Sharrett, L. A. Kingsley, W. Post, F. J. Palella, B. Visscher, and S. J. Gange. 2006. C-reactive protein is a marker for human immunodeficiency virus disease progression. Arch. Intern. Med. 166:64-70.

3. Achhra AC, Petoumenos K, Law MG. Relationship between CD4 cell count and serious long-term complications among HIV-positive individuals. Curr Opin HIV AIDS 2014; 9: 63-71.

4. Melchior JC, Niyongabo T, Henzel D, Durack-Bown I, Henri SC, Boulier A. Malnutrition and wasting, immunodepression, and chronic inflammation as independent predictors of survival in HIV-infected patients. Nutrition 1999, Nov-Dec;15(11-12):865-9.

5. Szalai AJ, Agrawal A, Greenhough TJ, Volanakis JE. C-reactive protein: structural biology and host defense function. ClinChem Lab Med. 1999;37(3):265-270.

6. Dong Q, Wright JR. Expression of C-reactive protein by alveolar macrophages. J Immunol 1996;156(12):4815-4820.

7. Bentwich Z, Kalinkovich A, Weisman Z. Immune activation is a dominant factor in the pathogenesis of African AIDS. Immunol Today 1995;16:187-91. [PUBMED]

8. Rizzardini G, Piconi S, Ruzzante S, Fusi ML, Lukwiya M, Declich S, et al. Immunological activation markers in the serum of African and European HIV-seropositive and seronegative individuals. AIDS 1996;10:1535-42 [PUBMED]

9. McCune JM. The dynamics of CD4+T-cell depletion in HIV disease. Nature 2001;410:974-9. [PUBMED]

10. Douek DC. Disrupting T-cell homeostasis: How HIV-1 infection causes disease. AIDS Rev 2003;5:172-7. [PUBMED]

11. Brenchley JM, Price DA, Schacker TW, Asher TE, Silvestri G, Rao S, et al. Microbial translocation is a cause of systemic immune activation in chronic HIV infection. Nat Med 2006;12:1365-71. [PUBMED]

12. Brenchley JM, Price DA, Douek DC. HIV disease: Fallout from a mucosal catastrophe? Nat Immunol 2006;7:235-9 [PUBMED]

13. Zulu I, Hassan G, Njobvu RN, Dhaliwal W, Sianongo S, Kelly P.
Cytokine activation is predictive of mortality in Zambian patients with AIDS-related diarrhoea. BMC Infect Dis 2008;8:156. [PUBMED]

14. Schleicher, G. K., V. Herbert, A. Brink, S. Martin, R. Maraj, J. S. Galpin, and C. Feldman. 2005. Procalcitonin and C-reactive protein levels in HIV-positive subjects with tuberculosis and pneumonia. Eur. Respir. J. 25:688-692.

15. Monica Chaudhary, Bineeta Kashyap, Hitender Gautam, Sanjeev Saini, and Preena Bhalla. Viral Immunology. June 2008, 21(2): 263 266. doi:10.1089/vim.2007.0083.

16. Ugwu MC. Human serum protein and C-Reactive Protein levels among HIV infected subjects in uromi and its environs in Edo, Nigeria. IJBAIR, 2016, 5(3): 74-80.

17. Reingold JS et al. The Fat Redistribution and Metabolic Change in HIV Infection (FRAM) Study J Acquir Immune Defic Syndr. 2008 Jun $1 ; 48(2): 142-148$

18. Vishwanath A, Quaiser S, Khan R. Role of high-sensitivity C-reactive protein measurements in HIV patients. Indian J Sex Transm Dis [serial online] 2016 [cited 2016 Dec 30];37:123-8. Available from: http://www.ijstd.org/text.asp?2016/37/2/123/192127

19. Redd AD, Eaton KP, Kong X, et al. C-reactive protein levels increase during HIV-1 disease progression in Rakai, Uganda despite the absence of microbial translocation. Journal of acquired immune deficiency syndromes (1999). 2010;54(5):556-559. doi:10.1097/QAI.0b013 e3181e0cdea.

20. Drain PK, Kupka R, Msamanga GI, Urassa W, Mugusi F, Fawzi WW. C-reactive protein independently predicts HIV-related outcomes among women and children in a resource-poor setting. AIDS 2007; 21:2067-75.

21. S Bhagyabati Devi, Robinson Ningshen, Arvind G. Burden of Opportunistic Infections in HIV/AIDS Patients in the Highly Active Antiretroviral Therapy Era: A Regional Institute of Medical Sciences, Imphal Perspective; http://www.apiindia.org/medicine _update 2013/chap15.pdf

22. Tahir A, Yusuph H, Bakki B and Jibrin YB (2013). Correlation between c-reactive protein and CD4+ cell count in HIV-infected and HIV/PTB co-infected patients at the university of maiduguri teaching hospital (UMTH), Maiduguri, Nigeria. Front. Immunol. Conference Abstract: 15th International Congress of Immunology (ICI). doi: 10.338

23. Skogmar S, Schön T, Balcha TT, Sturegård E, Jansson M, Björkman P (2015) Plasma Levels of Neopterin and C-Reactive Protein (CRP) in Tuberculosis (TB) with and without HIV Coinfection in Relation to CD4 Cell Count. PLoS ONE 10(12): e0144292.

24. S. D. Lawn, A. D. Kerkhoff, M. Vogt, R. Wood. Diagnostic and prognostic value of serum C-reactive protein for screening for HIVassociated tuberculosis. INT J TUBERC LUNG DIS 2013 17(5):636643.

Copyright: (C) the author(s), 2019. It is an open-access article distributed under the terms of the Creative Commons Attribution License (CC BY 4.0), which permits authors to retain ownership of the copyright for their content, and allow anyone to download, reuse, reprint, modify, distribute and/or copy the content as long as the original authors and source are cited.

How to cite this article: Gahlot A, Gahlot P, Acharya J. A Cross Sectional Study on Correlation of Quantitative C - reactive protein With CD4 Count in Patients of HIV on Art .Acad. J Med. 2019;2(2):14-17.

DOI: dx.doi.org/10.21276/ajm.2019.2.2.5

Source of Support: Nil, Conflict of Interest: None declared. 